\title{
PENGARUH GANGGUAN PRIBADI, GANGGUAN EKSTERN DAN GANGGUAN ORGANISASI TERHADAP INDEPENDENSI PEMERIKSA (Studi Empiris pada Bpk RI Perwakilan Provinsi Maluku Utara)
}

\author{
Silvia Arvianti Vitalokasari \\ Yustiana Djailani \\ Universitas Khairun Ternate \\ Jl. Pertamina Kelurahan Gambesi Kota Ternate Selatan \\ Email: silvia.arvianti@gmail.com
}

Abstract

Affect of Personal Disturbance, External Disturbance, and Organizational Disturbance to Auditor's Independence (Empiris study at the state audit representation of North Moluccas province), under the guidance of Yustiana Djaelani, SE., M.Si as supervising as primary advisors and Resmiyati Ansar, SE., MSA., Ak as supervising members. This study aims to obtain empirical evidance about the affect of personal disturbance, external disturbance, and organizational disturbance to auditor's independence at the state representation of North Moluccas province. Population on this research amounted 61 auditor's at the state representation of the North Moluccas province. The sampling method using the census so the entire population was used as a sample. The method of analysis in this study using multiple regression analysis. This research prove that three independent variables used in this research only external disturbance, variable that effect to the auditor's independence, while personal disturbance variables and organizational disturbance did not effect to auditor's independence.

Keywords: personal disturbance, external disturbance, organizational disturbance, auditor's independence 
Abstrak

Pengaruh Gangguan Pribadi, Gangguan Ekstern dan Gangguan Organisasi Terhadap Independensi Pemeriksa (studi empiris pada Badan Pemeriksa Keuangan Republik Indonesia Perwakilan Provinsi Maluku Utara). Penelitian ini bertujuan untuk memperoleh bukti empiris tentang pengaruh gangguan pribadi, gangguan ekstern dan gangguan organisasi terhadap independensi pemeriksa pada Badan Pemeriksa Keuangan Republik Indonesia (BPK RI) perwakilan provinsi Maluku Utara. Populasi dalam penelitian ini berjumlah 61 staf pemeriksa pada Badan Pemeriksa Keuangan Republik Indonesia perwakilan provinsi Maluku Utara. Metode pengambilan sampel menggunakan metode sensus sehingga seluruh populasi dijadikan sampel. Metode analisis dalam penelitian ini menggunakan analisis regresi berganda. Hasil penelitian ini membuktikan bahwa dari ketiga variabel bebas yang digunakan dalam penelitian ini hanya variabel gangguan ekstern yang berpengaruh terhadap independensi pemeriksa, sedangkan variabel gangguan pribadi dan gangguan organisasi tidak berpengaruh terhadap independensi pemeriksa.

Kata kunci: gangguan pribadi, gangguan ekstern, gangguan organisasi, independensi pemeriksa

\section{PENDAHULUAN}

Meningkatnya kasus korupsi yang terjadi hampir di sebagian besar organisasi pemerintah menyebabkan turunnya tingkat kepercayaan masyarakat terhadap kinerja pemerintah, tak terkecuali kinerja organisasi pemerintah yang ditugasi untuk melakukan pemeriksaan baik pemeriksaan yang bersifat keuangan maupun non keuangan. Kasus korupsi proyek hambalang yang hingga kini belum terselesaikan dan banyak menyita perhatian masyarakat menjadi catatan penting bagi pemerintah, pembangunan wisma atlet itu terkesan carut-marut dan banyak diwarnai pelanggaran oleh oknum yang terlibat dalam penanganan proyek tersebut. Hal ini semakin mencederai kepercayaan masyarakat atas kinerja para pejabat pemerintah dalam pengelolahan keuangan negara, untuk itu diperlukan suatu organisasi yang independen sehingga dapat menekan praktek kecurangan tersebut.

Organisasi pemerintah yang ditugasi untuk melakukan pemeriksaan seharusnya mampu mendeteksi pelanggaran yang dilakukan oleh oknum pejabat pemerintah yang tidak bertanggung jawab dalam pengelolahan keuangan negara, sehingga para pemeriksa dapat memberikan laporan hasil pemeriksaan yang berkualitas. Seorang pemeriksa harus bersikap independen dalam melaksanakan pemeriksaan serta menghindari keadaan-keadaan yang dapat mengakibatkan masyarakat meragukan independensinya. Para pengguna informasi keuangan mengharapkan laporan yang 
dihasilkan oleh seorang auditor (pemeriksa) dapat dipercaya dan akuntabel, oleh karena itu dibutuhkan jasa profesional pemeriksa yang independen dan objektif.

Menurut Mulyadi (1989:29-30) independensi berarti bebas dari pengaruh, tidak dikendalikan oleh pihak lain, tidak tergantung pada orang lain. Auditor pemerintah adalah auditor profesional yang bekerja di instansi pemerintah. Tugas pokoknya melakukan audit atas pertanggungjawaban keuangan yang disajikan oleh unit-unit organisasi atau entitas pemerintahan atau pertanggungjawaban keuangan yang ditujukan kepada pemerintah. Meskipun terdapat banyak auditor yang bekerja di instansi pemerintah, namun umumnya yang disebut auditor pemerintah adalah auditor yang bekerja di Badan Pengawasan Keuangan dan Pembangunan (BPKP) dan Badan Pemeriksa Keuangan (BPK), serta instansi pajak (Arnan, dkk., 2009:6).

Adapun peraturan yang telah ditetapkan oleh pemerintah mengenai fungsi, tugas dan tanggung jawab seorang auditor pemerintah yang termuat dalam Peraturan Badan Pemeriksa Keuangan RI Nomor 01 tahun 2007 tentang Standar pemeriksaan Keuangan Negara. Pada Lampiran II peraturan tersebut, pernyataan standar umum kedua pada alinea empat belas menyatakan: "Dalam semua hal yang berkaitan dengan pekerjaan pemeriksaan, organisasi pemeriksa dan pemeriksa, harus bebas dalam sikap mental dan penampilan dari gangguan pribadi, ekstern, dan organisasi yang dapat mempengaruhi independensinya".

Suatu organisasi pemeriksa dan para pemeriksa bertanggung jawab untuk dapat mempertahankan independensi sedemikian rupa, sehingga pendapat, simpulan, pertimbangan atau rekomendasi dari hasil pemeriksaan yang dilaksanakan dipandang tidak memihak oleh pihak mana pun. Hal ini sejalan dengan penelitian Subhan yang menyimpulkan bahwa berdasarkan uji F menunjukkan bahwa secara simultan variabel kecermatan profesi, obyektivitas, independensi dan kepatuhan terhadap kode etik mempengaruhi kualitas hasil pemeriksaan. Berdasarkan hasil pengujian menunujukkan bahwa variabel independensi secara parsial berpengaruh signifikan terhadap kualitas hasil pemeriksaan.

Guna memperoleh hasil audit yang berkualitas para pemeriksa harus bersikap independen dalam melaksanakan tugasnya, laporan hasil pemeriksaan atas Laporan Keuangan Pemerintah Daerah (LKPD) pada tahun 2008 BPK memberikan opini tidak menyatakan pendapat (disclaimer) atas seluruh LKPD yang ada di Maluku Utara hal ini dikerenakan tiga faktor yaitu: (1) Sistem Pengendalian Internal (SPI) pemerintah daerah tersebut masih lemah dalam hal pengendalian aset, dokumen, dan pembuatan laporan keuangan. (2) Ketidakpatuhan terhadap peraturan perundangundangan yang berlaku. (3) Lingkup pemeriksaan dibatasi oleh entitas yang diperiksa.

Tahun 2009, BPK memberikan opini tidak wajar kepada Kabupaten Halmahera Selatan, Kabupeten Halmahera Tengah, Kabupaten Halmahera Utara, Kabupaten Halmahera Barat, Kabupaten Halmahera Timur, Kabupaten Kepulauan Sula dan Kota Ternate, sedangkan Kota Tidore Kepulauan mendapat opini wajar dengan pengecualian (WDP), alasan pemberian opini tidak wajar ini menyangkut 
ketidakpatuhan terhadap perundang-undangan, dan penyajian laporan keuangan yang tidak wajar.

Tahun 2010, BPK tidak memberikan opini (Disclaimer). BPK memberikan opini tidak wajar kepada Kabupaten Halmahera Selatan, Kabupeten Halmahera Tengah, Kabupaten Halmahera Utara, Kabupaten Halmahera Barat, Kabupaten Halmahera Timur, Kabupaten Kepulauan Sula dan Kota Ternate, sedangkan Kota Tidore Kepulauan mendapat opini wajar dengan pengecualian (WDP). Hal ini menandakan bahwa Sistem Pengendalian Internal Kabupaten/Kota tidak dijalankan secara maksimal. Salah satu tugas APIP yaitu menjalankan sistem pengendalian internal pemerintahan Kabupaten/Kota.

Tahun 2011, BPK memberikan opini wajar dengan pengecualian (WDP) kepada Kabupaten Halmahera Selatan, Kota Tidore kepulauan dan Kota Ternate. Dengan demikian maka dapat dikatakan bahwa APIP belum memiliki kompetensi yang baik dalam menjalankan tugasnya untuk menghasilkan laporan keuangan pemerintah daerah yang berkualitas.

Hasil evaluasi oleh BPK menunjukkan bahwa LKPD yang memperoleh opini wajar dengan pengecualian (unqualified opini) pada umumnya memiliki pengendalian intern telah memadai. Adapun LKPD yang memperoleh opini tidak wajar (adverse opini) dan tidak menyatakan pendapatan (disclaimer opini) memerlukan perbaikan pengendalian intern dalam hal keandalan informasi yang disajikan dalam laporan keuangan. Masih banyaknya opini tidak wajar (adverse opini) dan tidak menyatakan pendapatan (disclaimer opini) yang diberikan oleh BPK menunjukkan efektivitas SPI pemerintah daerah belum optimal. BPK menemukan beberapa kasus kelemahan sistem pengendalian akuntansi dan pelaporan, terdiri atas: (1) Pencatatan tidak/belum dilakukan secara akurat. (2) Proses penyusunan laporan tidak sesuai dengan ketentuan. (3) Terlambat menyampaikan. (4) Sistem informasi akuntansi dan pelaporan tidak memadai. (5) Sistem informasi akuntansi dan pelaporan belum didukung SDM yang memadai.

Adanya suatu aturan yang mengikat mengenai pentingnya indepedensi bagi seorang pemeriksa, sangat mempengaruhi komitmen independensi yang dimiliki. Alinea tujuh belas dalam Peraturan Badan Pemeriksa Keuangan RI Nomor 01 tahun 2007 tanggal 7 Mei 2007 tentang Standar Pemeriksaan Keuangan Negara, Lampiran II menyatakan bahwa pemeriksa perlu mempertimbangkan tiga gangguan yang dapat mempengaruhi independensinya. Ketiga gangguan tersebut antara lain: gangguan pribadi, gangguan ekstern dan gangguan organisasi. Apabila satu atau lebih dari gangguan independensi tersebut mempengaruhi kemampuan pemeriksa secara individu dalam melaksanakan tugas pemeriksaannya, maka pemeriksa tersebut harus menolak penugasan pemeriksaan. Dalam keadaan pemeriksa yang karena suatu hal tidak dapat menolak penugasan pemeriksaan, gangguan dimaksud harus dimuat dalam bagian lingkup pada laporan hasil pemeriksaan. 
Penelitian mengenai independensi auditor (pemeriksa) telah banyak dilakukan. Diantaranya pada penelitian Kasidi (2007) menyimpulkan bahwa dari kelima variabel yang digunakan oleh peneliti hanya satu variabel yang berpengaruh terhadap independensi auditor yakni variabel komite audit.

Siregar (2009) menyimpulkan bahwa gangguan pribadi, ekstern dan organisasi memiliki pengaruh yang signifikan baik secara simultan maupun secara parsial terhadap independensi pemeriksa. Sedangkan Sriyanto (2010) menggunakan variabel gangguan pribadi, gangguan ekstern, gangguan organisasi dan kecakapan profesional terhadap independensi pemeriksa. Menyimpulkan bahwa secara simultan dan secara parsial keempat variabel yang digunakan berpengaruh terhadap independensi pemeriksa. Mide (2011) melakukan penelitian yang sama dengan penelitian Siregar (2009) dengan menghilangkan satu variabel yakni gangguan organisasi. Ia menyimpulkan bahwa variabel gangguan pribadi dan gangguan ekstern berpengaruh terhadap independensi auditor.

Menyikapi fenomena meningkatnya kasus korupsi dan krisis kepercayaan masyarakat terhadap independensi organisasi pemerintah yang ditugasi melakukan pemeriksaan, maka peneliti tertarik untuk melakukan penelitian ini. Selain itu peneliti ingin membuktikan hasil-hasil penelitian terdahulu guna memperoleh bukti empiris mengenai pengaruh gangguan pribadi, gangguan ekstern dan gangguan organisasi terhadap independensi pemeriksa (studi empiris pada Badan Pemeriksa Keuangan (BPK) Republik Indonesia Perwakilan Provinsi Maluku Utara).

Berdasarkan latar belakang tersebut, maka rumusan masalah yang akan dijadikan bahan penelitian adalah apakah gangguan pribadi, gangguan ekstern dan gangguan organisasi berpengaruh terhadap independensi pemeriksa. Adapun tujuan dari penelitian ini untuk memperoleh bukti empiris gangguan pribadi, gangguan ekstern dan gangguan organisasi berpengaruh terhadap indepedensi pemeriksa pada BPK RI perwakilan provinsi Maluku Utara.

Penelitian ini diharapkan dapat memberikan manfaat kepada berbagai pihak, antara lain bagi organisasi terkait, sebagai bahan referensi dan evaluasi guna peningkatan kinerja para staf pemeriksa, bagi akademisi penelitian ini diharapkan dapat menambah khazanah keilmuan yang berkaitan dengan audit khususnya mengenai gangguan pribadi, gangguan ekstern dan gangguan organisasi terhadap independensi pemeriksa, dan bagi peneliti selanjutnya, sebagai referensi tambahan mengenai gangguan-gangguan yang dapat mempengaruhi independensi pemeriksa.

\section{TINJAUAN PUSTAKA}

\section{Gangguan Pribadi}

Ilmu psikologi memiliki banyak teori, dari berbagai teori yang dimiliki ada sebuah teori yang relevan dengan gangguan kepribadian. Teori tersebut adalah teori neurosis yang dicetuskan oleh Karen Horney. Horney menawarkan cara pandang yang 
berbeda dalam melihat masalah neurosis. Ia berpendapat bahwa sebenarnya neurosis adalah cara yang digunakan manusia dalam menjalani hubungan dengan manusia lainnya. Akan tetapi, hanya ada sebagian yang melakukannya dengan baik. Orang yang menderita neurotik justru cenderung membiarkan dirinya hidup dalam dunianya sendiri (Khadra, 2012).

Gangguan kepribadian adalah pola prilaku atau cara berhubungan dengan orang lain yang benar-benar kaku. Kekakuan tersebut menghalangi mereka untuk menyesuaikan diri terhadap tuntutan eksternal, sehingga pola tersebut pada akhirnya bersifat self-defeating (Nevid, et al., 2003:273).

Peraturan Badan Pemeriksa Keuangan RI Nomor 01 tahun 2007 tanggal 7 Mei 2007 tentang Standar Pemeriksaan Keuangan Negara, Lampiran II. Pernyataan Standar Umum kedua pada alinea sembilan belas menyebutkan, organisasi pemeriksa harus memiliki sistem pengendalian mutu intern untuk membantu menentukan apakah pemeriksa memiliki gangguan pribadi terhadap independensi. Organisasi pemeriksa perlu memperhatikan gangguan pribadi terhadap independensi petugas pemeriksa. Gangguan pribadi yang disebabkan oleh suatu hubungan dan pandangan pribadi mungkin mengakibatkan pemeriksa membatasi lingkup pertanyaan dan pengungkapan atau melemahkan temuan dalam segala bentuknya.

\section{Gangguan Ekstern}

Gangguan ekstern bagi organisasi pemeriksa dapat membatasi pelaksanaan pemeriksaan atau mempengaruhi kemampuan pemeriksa dalam menyatakan pendapat atau simpulan hasil pemeriksaan secara independen dan obyektif. Independensi dan obyektivitas pelaksanaan suatu pemeriksaan dapat dipengaruhi apabila terdapat: (a) Campur tangan atau pengaruh pihak ekstern yang membatasi atau mengubah lingkup pemeriksaan secara tidak semestinya. (b) Campur tangan pihak ekstern terhadap pemilihan dan penerapan prosedur pemeriksaan atau pemilihan sampel pemeriksaan. (c) Pembatasan waktu yang tidak wajar untuk penyelesaian suatu pemeriksaan. (d) Campur tangan pihak ekstern mengenai penugasan, penunjukan, dan promosi pemeriksa. (e) Pembatasan terhadap sumber daya yang disediakan bagi organisasi pemeriksa, yang dapat berdampak negatif terhadap kemampuan organisasi pemeriksa tersebut dalam melaksanakan pemeriksaan. (f) Wewenang untuk menolak atau mempengaruhi pertimbangan pemeriksa terhadap isi suatu laporan hasil pemeriksaan. (g) Ancaman penggantian petugas pemeriksa atas ketidaksetujuan dengan isi laporan hasil pemeriksaan, simpulan pemeriksa, atau penerapan suatu prinsip akuntansi atau kriteria lainnya. (h) Pengaruh yang membahayakan kelangsungan pemeriksa sebagai pegawai, selain sebab-sebab yang berkaitan dengan kecakapan pemeriksa atau kebutuhan pemeriksaan. 


\section{Gangguan Organisasi}

Independensi organisasi pemeriksa dapat dipengaruhi oleh kedudukan, fungsi, dan struktur organisasinya. Dalam hal melakukan pemeriksaan, organisasi pemeriksa harus bebas dari hambatan independensi. Pemeriksa yang ditugasi oleh organisasi pemeriksa dapat dipandang bebas dari gangguan terhadap independensi secara organisasi, apabila melakukan pemeriksaan di luar entitas tempat ia bekerja.

Guna menghindarkan pemeriksa dari gangguan organisasi standar pemeriksaan harus mengatur secara lebih jelas dan mendalam mengenai hal tersebut agar tidak terdapat perbedaan persepsi yang dikhawatirkan akan menganggu pemeriksa dalam pelaksanaan tugas dan fungsinya. Bagi pemeriksa, dengan adanya standar yang lebih jelas yang mengatur independensi organisasi dapat memudahkan untuk bertindak dan keleluasaan mengambil keputusan dalam pemeriksaan mulai dari perencanaan hingga pembuatan laporan hasil pemeriksaan.

\section{Independensi Pemeriksa (Auditor)}

Tulang punggung akuntan publik profesional adalah independensi auditor. Ini dibuktikan oleh fakta bahwa indepedensi itu dengan jelas dimuat dalam kode etik dan di dalam norma pemeriksa akuntan. Independensi harus ditafsirkan sebagai bebas dari bujukan, pengaruh, atau pengendalian klien atau dari siapapun juga yang mempunyai kepentingan dengan audit. Jika auditor mengikuti kemauan klien yang berlawanan dengan pertimbangannya sendiri, maka pendapat yang dikemukakan auditor tidak ada artinya (Holmes dan Burns, 1993:78).

Standar Profesional Akuntan Publik (2011) SA Seksi 220 PSA No. 04 pada alinea 02 menyatakan mengharuskan auditor bersikap independen, artinya tidak mudah dipengaruhi, karena ia melaksanakan pekerjaannya untuk kepentingan umum (dibedakan dalam hal ia berpraktik sebagai auditor intern).

Peraturan Badan Pemeriksa Keuangan RI Nomor 01 tahun 2007 tanggal 7 Mei 2007 tentang Standar Pemeriksaan Keuangan Negara, Lampiran II. Pernyataan Standar Umum kedua pada alinea empat belas menyatakan: "Dalam semua hal yang berkaitan dengan pekerjaan pemeriksaan, organisasi pemeriksa dan pemeriksa, harus bebas dalam sikap mental dan penampilan dari gangguan pribadi, ekstern, dan organisasi yang dapat mempengaruhi independensinya”.

Peraturan Badan Pemeriksa Keuangan RI Nomor 2 tahun 2011 tanggal 7 Oktober 2011 tentang kode etik pemeriksa, bab 1 ketentuan umum pada pasal 1 menyatakan: independensi adalah suatu sikap dan tindakan dalam melaksanakan pemeriksaan untuk tidak memihak kepada siapa pun dan tidak dipengaruhi oleh siapa pun. 


\section{METODE PENELITIAN}

Penelitian ini dilakukan pada Badan Pemeriksa Keuangan (BPK) Republik Indonesia Perwakilan Provinsi Maluku Utara yang beralamat di Jalan Raya Jati. Sedangkan jangka waktu dalam melakukan penelitian ini selama bulan Mei sampai Agustus 2013. Populasi dalam penelitian ini sebanyak 61 orang yang meliputi seluruh staf pemeriksa pada Badan Pemeriksa Keuangan (BPK) RI Perwakilan Provinsi Maluku Utara. Penelitian ini menggunakan sampel jenuh, menurut Sugiono (2008: 122) sampel jenuh adalah teknik penentuan sampel bila semua anggota populasi digunakan sebagai sampel. Istilah lain sampel jenuh adalah sensus, dimana semua anggota populasi dijadikan sampel.

Jenis data yang digunakan dalam penelitian ini berupa data kuantitatif yang didapat dari nilai atau skor atas jawaban yang diberikan oleh responden terhadap pertanyaan-pertanyaan yang terdapat dalam kuesioner. Penelitian ini menggunakan sumber data primer, yaitu data yang diperoleh peneliti secara langsung dari objek penelitian dan tidak melalui media perantara.

Metode pengumpulan data dalam penelitian ini menggunakan kuesioner. Menurut Sugiono (2008:199) Kuesioner merupakan teknik pengumpulan data yang dilakukan dengan cara memberi seperangkat pertanyaan atau pernyataan tertulis kepada responden untuk dijawabnya. Kuesioner dalam penelitian ini menggunakan kusioner dari penelitian Siregar (2009) yang telah disesuaikan dan mengacu pada Peraturan Badan Pemeriksa Keuangan RI Nomor 01 tahun 2007 tanggal 7 Mei 2007 tentang Standar Pemeriksaan Keuangan Negara.

Metode analisis dalam penelitian ini adalah menggunakan analisis regresi berganda. Analisis regresi berganda adalah teknik statistik melalui koefisien parameter untuk mengetahui besarnya pengaruh variabel independen terhadap variabel dependen. Pengujian terhadap hipotesis baik secara parsial maupun simultan, dilakukan setelah model regresi yang digunakan bebas dari pelanggaran asumsi klasik. Tujuannya adalah agar hasil penelitian dapat diinterpretasikan secara tepat dan efisien. Persamaan regresi tersebut adalah sebagai berikut:

$\mathrm{Y}=\mathrm{a}+\mathrm{b} 1 \mathrm{X} 1+\mathrm{b} 2 \mathrm{X} 2+\mathrm{b} 3 \mathrm{X} 3+\mathrm{e}$

\section{Keterangan:}

$\mathrm{Y} \quad=$ Independensi pemeriksa

a $\quad$ Konstanta

$\mathrm{b} \quad=$ Koefisien Regresi

$\mathrm{X} 1$ = Gangguan Pribadi

$\mathrm{X} 2$ = Gangguan Ekstern

$\mathrm{X} 3$ = Gangguan Organisasi

$\mathrm{e} \quad=$ Tingkat Kesalahan

Pengaruh variabel independen terhadap variabel dependen diuji dengan tingkat kepercayaan (confidence interval) $95 \%$ atau $\alpha=5 \%$. 
Komitmen pengukuran dan pengujian suatu kuesioner atau hipotesis sangat bergantung pada kualitas data yang dipakai dalam pengujian tersebut. Data penelitian tidak akan berguna jika instrumen yang digunakan untuk mengumpulkan data penelitian tidak memiliki reability (tingkat keandalan) dan validity (tingkat kebenaran/ keabsahan yang tinggi). Pengujian validitas dan reabilitas kuesioner dalam penelitian ini menggunakan program SPSS (Statistical Product and Service Solution).

Model regresi linier berganda (multiple regression) dapat disebut sebagai model yang baik jika model tersebut memenuhi beberapa asumsi yang kemudian disebut dengan asumsi klasik. Proses pengujian asumsi klasik dilakukan bersama dengan proses uji regresi sehingga langkah-langkah yang dilakukan dalam pengujian asumsi klasik menggunakan langkah kerja yang sama dengan uji regresi. Ada lima uji asumsi yang harus dilakukan terhadap suatu model regresi tersebut yaitu uji normalitas, autokorelasi, uji linieritas, uji multikolinieritas, dan uji heteroskedastisitas.

\section{HASIL DAN PEMBAHASAN}

Penelitian ini mengambil objek pada BPK RI perwakilan provinsi Maluku Utara yang mulai beroperasi kurang lebih enam tahun. Menurut peneliti objek penelitian cukup menarik dikarenakan BPK RI belum lama beroperasi, sehingga belum banyak penelitian lain yang mengambil objek yang sama. Selain itu hasil penelitian ini diharapkan dapat menambah khazanah keilmuan mengenai audit yang dilakukan pada instansi pemerintah serta seberapa besar komitmen independensi staf pemeriksa yang bekerja pada BPK RI Maluku Utara.

Penelitian ini menggunakan kuesioner yang diedarkan langsung kepada 61 staf pemeriksa yang bekerja di BPK RI Perwakilan Provinsi Maluku Utara. Dari 61 kuesioner yang diedarkan 58 kuesioner yang kembali, tiga kuesioner yang tidak kembali dikarenakan staf pemeriksa tidak mengembalikan kuesioner pada peneliti. Dari seluruh kuesioner yang kembali terdapat tiga kuesioner yang tidak dapat dijadikan sampel dalam penelitian ini dikarenakan responden tidak menjawab keseluruhan item pertanyaan yang diajukan.

Staf pemeriksa di BPK RI Perwakilan Provinsi Maluku Utara yang dijadikan sampel sebagian besar berjenis kelamin laki-laki dengan jumlah 50 orang $(90,91 \%)$ dan sisanya sebanyak 5 orang $(9,09 \%)$ berjenis kelamin perempuan. Berdasarkan masa kerja staf pemeriksa di BPK RI Perwakilan Provinsi Maluku Utara yang dijadikan sampel sebagian besar mempunyai masa kerja antara 0 sampai 4 tahun sebesar 60\% sebanyak 33 orang, sedangkan yang masa kerja 5 sampai 9 tahun sebesar $29,09 \%$ sebanyak 16 orang dan sisanya memiliki masa kerja antara 10 sampai 15 tahun sebesar 10,91\% sebanyak 6 orang.

Pengujian validitas instrumen dalam penelitian ini menggunakan software SPSS versi 20, nilai validitas dapat dilihat pada kolom Corrected Item-Total Correlation. Jika nilai $\mathrm{r}_{\text {hitung }}$ yang merupakan nilai dari Corrected Item-Total Correlation> dari 
$\mathrm{r}_{\text {tabel }}$ maka instrumen tersebut dinyatakan valid. Dengan jumlah data atau $\mathrm{N}=55$ dengan taraf signifikansi $5 \%$ maka nilai $r_{\text {tabel }}$ dalam penelitian ini sebesar 0,266.

Hasil pengujian validitas yang dibantu dengan software SPSS versi 20 memperlihatkan bahwa seluruh instrumen pertanyaan pada tiga variabel independen yang digunakan dalam penelitian ini yakni variabel gangguan pribadi, gangguan ekstern dan gangguan organisasi memiliki nilai $r_{\text {hitung }}$ yang merupakan nilai dari corrected item-total correlation lebih besar dari nilai $r_{\text {tabel }} 0,266$ dengan $n=55$ pada tingkat signifikansi 0,05 , hal ini berarti seluruh instrumen pertanyaan dinyatakan valid.

Instrumen pertanyaan pada variabel independensi pemeriksa (y) setelah dilakukan pengujian validitas terdapat satu instrumen yang tidak valid, yaitu pada item keempat. Jika sebuah butir tidak valid maka otomatis butir tersebut dibuang dan butir-butir pertanyaan yang valid kemudian secara bersama-sama diukur reabilitasnya (Singgih dalam Sunyoto 2011:69).

Item yang keempat pada variabel (y) tidak valid menurut peneliti muncul karena item keempat memuat tentang jika seorang pemeriksa melaksanakan pemeriksaan lebih dari tiga tahun secara berturut-turut maka tidak semua kesalahan entitas pemeriksa laporkan. Dalam pertanyaan tersebut jawaban responden sebagian besar menyatakan ketidaksetujuan sehingga jika dibandingkan dengan jawaban responden pada item yang lain sangat berbeda jauh, ini yang menyebabkan item tersebut tidak valid. Setelah dilakukan penghapusan pada item keempat peneliti menguji kembali validitas instrumen yang digunakan dan hasilnya seluruh instrumen pada variabel independensi pemeriksa (y) dinyatakan valid.

Setelah melakukan pengujian validitas instrumen langkah selanjutnya adalah melakukan pengujian reabilitas instrumen, pengujian reabilitas dalam penelitian ini menggunakan software SPSS versi 20. Reabilitas suatu variabel yang dibentuk dari daftar pertanyaan dikatakan baik jika memiliki nilai Cronbach's Alpha > dari 0,60 . Hasil pengujian reabilitas menunjukan bahwa semua variabel memiliki nilai cronbach's alpha di atas 0,60 itu artinya semua instrumen pertanyaan yang digunakan pada variabel penelitian ini reliabel.

\section{Deskripsi Data Penelitian}

Tabel 1. Analisis Statistik Deskriptif

\begin{tabular}{lccccc}
\hline & N & Minimum & Maximum & Mean & Std. Deviation \\
\hline Gangguan Pribadi & 55 & 23,00 & 60,00 & 44,4909 & 9,24136 \\
Gagguan Ekstern & 55 & 15,00 & 40,00 & 29,6364 & 6,22529 \\
Gangguan Organisasi & 55 & 4,00 & 10,00 & 7,1091 & 1,65185 \\
Independensi Pemeriksa & 55 & 10,00 & 25,00 & 21,2182 & 2,37027 \\
\hline
\end{tabular}

Sumber: Data primer yang diolah dengan SPSS statistik 20 
Dari hasil perhitungan statistik deskriptif dengan bantuan software SPSS versi 20 diperoleh nilai minimum variabel gangguan pribadi sebesar 23 dan nilai maksimum sebesar 60 dengan rata-rata 44 serta standar deviasi 9,2. Adapun penjelasan nilainilai dari setiap variabel tersaji pada tabel berikut: Pengujian normalitas data bertujuan untuk melihat apakah variabel penganggu atau residual berdistribusi normal, pada penelitian ini pengujian normalitas data menggunakan software SPSS versi 20 dengan menggunakan analisis one sample kolmogorov-smirnov test dengan melihat nilai signifikansi residual. Jika signifikansi lebih dari 0,05 , maka residual terdistribusi secara normal. Hasil uji normalitas dapat dilihat pada tabel 2.

Tabel 2. Hasil Uji Normalitas dengan One Sample Kolmogorov-Smirnov Test One Sample Kolmogorov-Smirnov

\begin{tabular}{ll}
\hline & Unstandardized Residual \\
\hline Kolmogorov-Smirnov $Z$ & 1,609 \\
Asymp. Sig. (2-tailed) & 0,203 \\
\hline
\end{tabular}

Sumber: data primer yang diolah dengan SPSS statistic 20

Hasil pengujian normalitas pada tabel 2 terlihat bahwa nilai signifikansi yaitu Asymp. Sig (2-tailed) bernilai $0.203>0.05$ sehingga disimpulkan bahwa residual telah memenuhi asumsi distribusi normal. Uji multikolinieritas dalam penelitian ini dilakukan dengan SPSS versi 20 dilakukan dengan uji regresi, dengan patokan nilai VIF (variance inflation factor) dan koefisien korelasi antar variabel bebas. Kriteria yang digunakan adalah: jika nilai VIF kurang dari 10 dan memiliki tolerance mendekati 1, maka dikatakan tidak terdapat masalah multikolinieritas dalam model regresi. Hasil uji multikolinieritas dapat dilihat pada tabel 3 di bawah ini:

Tabel 3. Hasil Uji Multikolonieritas

Hasil uji multikolinieritas

\begin{tabular}{lllc}
\hline \multirow{2}{*}{ Model } & & \multicolumn{2}{c}{ Collinearity Statistics } \\
\cline { 3 - 4 } & & Tolerance & VIF \\
\hline \multirow{2}{*}{1} & (constant) & & \\
& Gangguan pribadi & 0,460 & 2,175 \\
& Gangguan ekstern & 0,477 & 2,097 \\
& Gangguan Organisasi & 0,495 & 2,018 \\
\hline
\end{tabular}

Sumber: data primer yang diolah dengan SPSS statistic 20

Berdasarkan tabel 3 di atas terlihat bahwa dari ketiga variabel independen memiliki nilai tolerance mendekati 1 dan nilai VIF kurang dari 10 maka dinyatakan variabel yang digunakan dalam penelitian ini tidak mengalami masalah multikolinieritas. 
Uji heteroskedastisitas bertujuan menguji apakah model regresi terjadi ketidaksamaan variance dari residual pengamatan ke pengamatan yang lain. Pengujian heteroskedastisitas dalam penelitian ini menggunakan software SPSS dengan analisis glejser. Uji glejser ditandai dengan menghasilkan nilai absolute residual terhadap variabel independen lainnya. Jika signifikansi antara variabel independen dengan residual lebih dari 0,05 maka tidak terjadi heteroskedastisitas. Hasil pengujian heteroskedastisitas terlihat pada:

Tabel 4. Hasil Uji Heteroskedastisitas

Hasil Uji Heteroskedastisitas

\begin{tabular}{lll}
\hline Model & & Sig. \\
\hline & & (constant) \\
\multirow{2}{*}{1} & Gangguan pribadi & 0,355 \\
& Gangguan ekstern & 0,180 \\
& Gangguan Organisasi & 0,214 \\
\hline
\end{tabular}

Sumber: data primer yang diolah dengan SPSS statistic 20

Hasil uji heteroskedastisitas menggunakan metode glejser terlihat bahwa dari ketiga variabel independen memiliki nilai signifikansi lebih dari 0,05 maka dapat dikatakan tidak terjadi heterokedastisitas pada model yang digunakan dalam penelitian ini.Model analisis dalam penelitian ini menggunakan regresi linier berganda untuk melihat tingkat signifikasi variabel bebas yakni gangguan pribadi, gangguan ekstern dan gangguan organisasi terhadap variabel terikat independensi pemeriksa. Hasil analisis regresi linier berganda tersaji pada tabel 5 .

Tabel 5. Rekapitulasi Hasil Analisis Regresi Berganda

Rekapitulasi Hasil Analisis Regresi Berganda

\begin{tabular}{llll}
\hline Variabel Independen & Koefisien Regresi & T & Sig. \\
\hline Gangguan Pribadi (X1) & 0,004 & 0,090 & 0,928 \\
Gangguan Ekstern (X2) & 0,159 & 2,463 & 0,017 \\
Gangguan Organisasi (X3) & 0,229 & 0,959 & 0,342 \\
\hline Constant & 14,690 & & \\
R & 0,546 & & \\
R Square & 0,299 & & \\
Adjust $R$ Square & 0,257 & & 0,000 \\
F & 7,237 & & \\
\hline
\end{tabular}

Sumber: data primer yang diolah dengan SPSS statistic 20 
Berdasarkan perhitungan yang dibantu dengan software SPSS versi 20, maka diperoleh rekapitulasi hasil analisis regresi linier berganda seperti terlihat pada tabel 5 di atas dengan menggunakan taraf signifikansi 0,05 didapat persamaan regresi dalam penelitian ini sebagai berikut: $\mathrm{Y}=14,690+0,004 \mathrm{X} 1+0,159 \mathrm{X} 2+0,229 \mathrm{X} 3+\mathrm{e}$

Persamaan regresi tersebut dapat diketahui nilai konstanta sebesar 14,690 dapat diartikan jika variabel bebas dalam model diasumsikan bernilai nol, secara rata-rata variabel di luar model akan meningkatkan variabel independensi pemeriksa sebesar 14,690. Nilai koefisien regresi variabel gangguan pribadi sebesar 0,004, ini menunjukkan arah yang positif berarti bahwa ketika gangguan pribadi mengalami peningkatan sebesar satu satuan, independensi pemeriksa juga akan mengalami peningkatan gangguan sebesar 0,004 satuan. Nilai koefisien regresi dengan arah positif pada variabel gangguan ekstern sebesar 0,159 menunjukan bahwa ketika gangguan ekstern mengalami peningkatan sebesar satu satuan, independensi pemeriksa juga akan mengalami peningkatan gangguan sebesar 0,159 satuan. Nilai koefisien regresi variabel gangguan organisasi menunjukan arah positif dengan nilai sebesar 0,229 ini berarti bahwa ketika gangguan organisasi mengalami peningkatan sebesar satu satuan, independensi pemeriksa juga akan mengalami peningkatan gangguan sebesar 0,229 satuan. Hasil rekapitulasi analisis regresi linier berganda pada tabel 5 memperlihatkan nilai kofisien determinasi yang sudah disesuaikan (Adjusted $R$ square) sebesar 0,257 menunjukkan besarnya peran kontribusi variabel gangguan pribadi, gangguan ekstern dan gangguan organisasi mampu menjelaskan variabel independensi pemeriksa sebesar $25,7 \%$, dan sisanya sebesar $74,3 \%$ dijelaskan oleh variabel lain di luar variabel yang diteliti. Nilai adjusted $R$ square yang hanya $25,7 \%$ menunjukkan hubungan antara ketiga variabel independen dengan variabel dependen rendah. Untuk mengetahui pengaruh variabel bebas secara bersama-sama (simultan) terhadap variabel terikat perlu dilakukan uji F. Hasil uji F dengan taraf signifikansi 0,05 dengan sampel sebanyak 55 pada tabel 5 dapat dilihat pada Nilai probabilitas $F\left(\mathrm{~F}_{\text {hitung }}\right)$ dalam regresi berganda sebesar 7,237 dengan taraf signifikansi $0,000<0,05$ ini berarti bahwa variabel gangguan pribadi, gangguan ekstern dan gangguan organisasi secara bersama-sama berpengaruh terhadap independensi pemeriksa. Tabel 5 juga menjelaskan pengaruh variabel bebas terhadap variabel terikat secara parsial dengan taraf signifikansi sebesar 0,05 . Nilai signifikasi setiap variabel, adapun penjelasannya sebagai berikut: (1)Nilai signifikansi 0,928 > 0,05 ini berarti gangguan pribadi tidak berpengaruh terhadap independensi pemeriksa dengan demikian hipotesis pertama dalam penelitian ini ditolak. (2) Nilai signifikansi $0,017<0,05$ ini berarti gangguan ekstern berpengaruh terhadap independensi pemeriksa dengan demikian hipotesis kedua dalam penelitian ini diterima. (3) Nilai signifikansi 0,299>0,05 ini berarti gangguan organisasi tidak berpengaruh terhadap independensi pemeriksa dengan demikian hipotesis ketiga dalam penelitian ini ditolak. Hasil penelitian ini membuktikan bahwa dari ketiga variabel bebas yang digunakan 
dalam penelitian ini hanya variabel gangguan ekstern yang berpengaruh terhadap independensi pemeriksa, sedangkan variabel gangguan pribadi dan gangguan organisasi tidak berpengaruh terhadap independensi pemeriksa.Hipotesis pertama yang menyatakan bahwa gangguan pribadi berpengaruh terhadap independensi pemeriksa dalam penelitian ini ditolak. Hal ini dikarenakan salah satu faktor yang dapat memicu gangguan pribadi pada seorang pemeriksa adalah memiliki hubungan kekerabatan dengan orang-orang yang berada pada entitas yang diperiksa. Sedangkan sebagian besar staf pemeriksa yang bekerja di BPK RI perwakilan provinsi Maluku Utara berasal dari luar provinsi Maluku Utara sehingga kecil kemungkinan memiliki hubungan kekerabatan dengan orang-orang yang berada pada entitas yang diperiksa. Selain itu menurut peneliti jika dikaitkan dengan teori neurosis, dapat disimpulkan bahwa para staf pemeriksa yang bekerja di BPK RI Maluku Utara telah menggunakan cara yang tepat dalam menjalin hubungan dengan individu yang terdapat pada entitas yang diperiksa, sehingga pemeriksa dapat bersikap independen dan tidak mengalami gangguan secara pribadi. Serta dikarenakan tingkat pemahaman dan kepatuhan yang tinggi terhadap Peraturan Badan Pemeriksa Keuangan RI Nomor 2 tahun 2011 tanggal 7 Oktober 2011 tentang Kode Etik Pemeriksa serta Peraturan Badan Pemeriksa Keuangan RI Nomor 01 tahun 2007 tanggal 7 Mei 2007 tentang Standar Pemeriksaan Keuangan Negara, Lampiran II. Pernyataan Standar Umum kedua pada alinea empat belas menyatakan: "Dalam semua hal yang berkaitan dengan pekerjaan pemeriksaan, organisasi pemeriksa dan pemeriksa, harus bebas dalam sikap mental dan penampilan dari gangguan pribadi, ekstern, dan organisasi yang dapat mempengaruhi independensinya". Hasil penelitian ini mendukung penelitian Kasidi (2007) yang menyatakan pelayanan konsultasi manajemen dilakukan oleh auditor terhadap klien yang diaudit, merupakan salah satu indikator pada variabel gangguan pribadi tidak berpengaruh terhadap independensi auditor. Selain itu penelitian ini tidak sesuai dengan penelitian Siregar (2009), Sriyanto (2010) dan Mide (2011) yang menyatakan bahwa gangguan pribadi berpengaruh terhadap independensi pemeriksa.Gangguan ekstern berpengaruh terhadap independensi pemeriksa yang menjadi hipotesis kedua dalam penelitian ini diterima. Hasil penelitian ini sesuai dengan laporan hasil pemeriksaan yang disampaikan oleh BPK RI Perwakilan Provinsi Maluku Utara atas laporan keuangan pemerintah daerah (LKPD) pada tahun 2008 yang memberikan opini tidak menyatakan pendapat (disclaimer) atas seluruh LKPD yang ada di Maluku Utara salah satu faktornya adalah lingkup pemeriksaan dibatasi oleh entitas yang diperiksa. Lingkup pemeriksaan yang dibatasi oleh entitas yang diperiksa, merupakan salah satu indikator dari gangguan ekstern yang dapat mempengaruhi independensi seorang pemeriksa, sehingga jika seorang pemeriksa merasakan gangguan pada independensinya gangguan tersebut wajib dimuat dalam bagian lingkup pada laporan hasil pemeriksaan. Pada tahun-tahun berikutnya pemeriksa sudah tidak merasakan gangguan ekstern lagi ini terlihat dari opini disclaimer yang diberikan untuk tahun-tahun selanjutnya dikarenakan SPI 
pemerintah daerah masih lemah bukan karena lingkup pemeriksaan dibatasi oleh entitas yang diperiksa. Menurut peneliti faktor lainnya karena para staf pemeriksa yang bekerja di BPK RI Maluku Utara memiliki tingkat pemahaman dan kepatuhan yang tinggi terhadap Peraturan Badan Pemeriksa Keuangan RI Nomor 2 tahun 2011 tanggal 7 Oktober 2011 tentang Kode Etik Pemeriksa serta Peraturan Badan Pemeriksa Keuangan RI Nomor 01 tahun 2007 tanggal 7 Mei 2007 tentang Standar Pemeriksaan Keuangan Negara. Hasil penelitian ini sejalan dengan penelitian Siregar (2009), Sriyanto (2010) dan Mide (2011) menyatakan bahwa secara parsial gangguan ekstern berpengaruh terhadap independensi pemeriksa. Hasil pengujian hipotesis ketiga yang menyatakan bahwa gangguan organisasi berpengaruh terhadap independensi pemeriksa ditolak. Hal ini menurut peneliti dikarenakan seluruh staf pemeriksa pada BPK RI perwakilan Provinsi Maluku Utara melakukan pemeriksaan di luar entitas tempat ia bekerja, sehingga gangguan organisasi tidak dapat mempengaruhi independensi pemeriksa.Selain itu menurut peneliti para staf pemeriksa yang bekerja di BPK RI Maluku Utara memiliki tingkat pemahaman dan kepatuhan yang tinggi terhadap Peraturan Badan Pemeriksa Keuangan RI Nomor 2 tahun 2011 tanggal 7 Oktober 2011 tentang Kode Etik Pemeriksa serta Peraturan Badan Pemeriksa Keuangan RI Nomor 01 tahun 2007 tanggal 7 Mei 2007 tentang Standar Pemeriksaan Keuangan Negara. Hasil penelitian ini tidak mendukung penelitian Siregar (2009) dan Sriyanto (2010) yang menyatakan bahwa gangguan organisasi berpengaruh terhadap independensi pemeriksa.

\section{SIMPULAN}

Penelitian ini bertujuan mengetahui pengaruh gangguan pribadi, gangguan ekstern dan gangguan organisasi terhadap independensi pemeriksa pada BPK RI Perwakilan Provinsi Maluku Utara. Hasil penelitian ini memberikan kesimpulan bahwa: Pertama, Gangguan pribadi tidak berpengaruh terhadap independensi pemeriksa hal ini dikarenakan para staf pemeriksa pada BPK RI Maluku utara yang dijadikan responden pada penelitian ini sebagian besar berasal dari luar wilayah Maluku Utara. Sehingga kecil kemungkinan memiliki hubungan kekerabatan dengan orang yang terdapat pada entitas yang diperiksa. Hal ini memperkecil munculnya faktor yang dapat menjadi pemicu gangguan pribadi terhadap independensi. Kedua, Gangguan ekstern berpengaruh terhadap independensi pemeriksa dikarenakan para staf pemeriksa pada BPK RI Maluku Utara merasa lingkup pemeriksaan dibatasi oleh entitas yang diperiksa. Hal ini diungkapkan pada laporan hasil pemeriksaan atas laporan keuangan pemerintah daerah pada tahun 2008. Ketiga, Gangguan organisasi tidak berpengaruh terhadap independensi pemeriksa, ini dikarenakan seluruh staf pemeriksa yang terdapat di BPK RI Maluku Utara melaksanakan pemeriksaan di luar entitas ia bekerja. Sehingga pemeriksa tidak merasakan gangguan terhadap independensi secara organisasi.Beberapa keterbatasan dalam 
penelitian ini yang memungkinkan timbulnya bias dan ketidakakuratan dalam penelitian ini, antara lain: hasil penelitian ini hanya terbatas pada staf pemeriksa yang bekerja di BPK RI Perwakilan Provinsi Maluku Utara; penelitian ini hanya menggunakan kuesioner, sehingga memungkinkan kelemahan-kelemahan terjadi seperti jawaban responden yang asal-asalan dan tidak jujur, serta pertanyaan pada kuesioner yang kurang dipahami oleh responden; dan variabel yang digunakan untuk mengukur pengaruhnya terhadap independensi pemeriksa masih sangat terbatas. Terlihat nilai adjusted $R$ square dalam penelitian ini yang rendah, sangat memungkinkan variabel lain untuk mempengaruhi indepedensi pemeriksa, seperti lamanya kerja, maupun pengendalian perasaan dan emosi.Berdasarkan kesimpulan dan keterbatasan yang dikemukakan, maka dapat disampaikan bebarapa saran: bagi peneliti selanjutnya dapat memperluas objek penelitian, seperti pada KAP, Inspektorat, BPKP dan BPK RI seluruh Indonesia; bagi peneliti selanjutnya dapat menggunakan teknik pengumpulan data yang berbeda seperti teknik wawancara dan observasi; dan peneliti selanjutnya juga dapat menambahkan variabel lain yang memungkinkan untuk mempengaruhi independensi pemeriksa, seperti lamanya kerja, pengendalian perasaan dan emosi dll.

\section{DAFTAR PUSTAKA}

Arens and Loebbecke. 1997. Auditing. Jakarta: Salemba Empat.

Arnan, S.G., Nelsi, W., \& Indra, F. 2009. Auditing. Bandung: Politeknik Telkom Bandung.

Badan Pemeriksa Keuangan. 2007. Peraturan Badan Pemeriksa Keuangan RI Nomor 01

Tahun 2007 tentang Standar Pemeriksa Keuangan Republik Indonesia Tahun 2007. Jakarta.

Badan Pemeriksa Keuangan. 2011. Peraturan Badan Pemeriksa Keuangan RI Nomor 02 Tahun 2011 tentang kode etik pemeriksa Tahun 2011. Jakarta.

Holmes, W., Arthur, and David, C.B. 1993. Auditing Norma Dan Prosedur jilid 1 edisi kesembilan. Jakarta: Erlangga.

IAPI. 2011. Standar Profesional akuntan Publik. Jakarta: Salemba Empat.

Jenie, Arum, N.D. 2012. Statistik Deskriptif \& Regresi Linier Berganda Dengan SPSS. Semarang: Semarang University Press.

Kasidi. 2007. Faktor-Faktor Yang Mempengaruhi Independensi Auditor. Tesis. Semarang: Universitas Diponegoro.

Khadra, H.A. 2012. Karen Horney. http://khadranotes.blogspot.com. (diakses 07 oktober 2013).

Mide, Z.N. 2011. Pengaruh Gangguan Pribadi dan Gangguan Ekstern Terhadap Independensi Auditor. Skripsi. Makassar: Universitas Hasanuddin.

Mulyadi. 1989. Pemeriksaan Akuntan edisi 2. Yogyakarta: STIE YKPN.

Nevid, Jeffrey, S., Spencer, A., Rathus, and Beverly, G. 2003. Psikologi Abnormal. Jakarta: Erlangga. 